\title{
Medium, Nutrition, and Flower Induction in Potted Blooming Orchids
}

\author{
Yin-T ung W ang
}

D epartment of $\mathrm{H}$ orticultural Sciences, the Texas A\& M U niversity System Agricultural Research and Extension Center, 2415 East H ighway 83, Weslaco, TX 78596

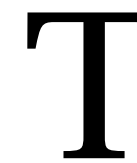

he most popular potted blooming orchids that are currently sold in the largest quantities are the phalaenopsis orchids (Phalaenopsis Blume.) and dendrobium orchids (D endrobium Swartz.). Commercially, bark from douglas fir [Pseudotsuga menziesi ( $M$ irb.) Franco] logs was the most widely used potting medium for growing these epiphytic orchids in containers. H owever, fresh bark does not retain adequate amounts of moisture and has been found to retain no nitrate-nitrogen. Small or medium grade douglas fir bark decomposes quickly, requiring frequent repotting to keep plant vigorous. Currently, most orchid growers still use fir bark, but in combination with various other materials, such as peat, rockwool, perlite, vermiculate, volcanic rock, etc. Peat, when mixed with bark, has been found to increase the retention of moisture and nutrients, including nitratenitrogen. Chopped coconut (C ocos nucifera L.) husks of various sizes have been used successfully for producing quality orchids. H owever, the high levels of salts that often associate with most chopped coconut husks must be removed prior to potting to avoid root injury.

When bark was used as the sole potting medium for growing orchids, fertilizers high in nitrogen, such as $30 \mathrm{~N}-4.4 \mathrm{P}-8.3 \mathrm{~K}(30-10-10)$ are recommended to avoid the possibility of $\mathrm{N}$ deficiency. $\mathrm{H}$ owever, since bark does not retain much nutrients, much of the N, particularly that in the form of urea, is probably lost through leaching. In a mix containing $80 \%$ fir bark and $20 \%$ peat, it was found that six soluble fertilizers of various $\mathrm{N}-\mathrm{P}-\mathrm{K}$ ratios and acid-forming capacities, with or without urea, resulted in equal vegetative growth and flowering. There was no difference in flower count or size. The preliminary results form an ongoing experiment show that foliar application of fertilizer as the sole source of nutrients does not appear to be adequate for optimal growth of phalaenopsis orchids. As the rate of a $20 \mathrm{~N}$ 8.6P-16.6K (20-20-20) fertilizer in the irrigation water increases from 0.25 to 1.0 $\mathrm{g} \cdot \mathrm{L}^{-1}$ (250 to $1000 \mathrm{ppm}$ ), vegetative growth is dramatically improved. Also, as fertilizer rate increased, bloom date becomes earlier with more flowers being produced. M edium particle size and fertilizer application frequency have also been found to affect growth and flowering of dendrobium orchids. Fertilizing $\left(1.0 \mathrm{~g}^{\cdot \mathrm{L}^{-1}}\right)$ at each watering improves shoot growth and flowering of dendrobium orchids over once every three waterings. The addition of peat to large size fir bark results in 
more flowers being produced than the plants in bark alone. Increased salinity of irrigation water results in increased injury to the root system of phalaenopsis orchids. H owever, flower count and the concentration of most mineral nutrients in leaves are unaffected.

The species and hybrids of phalaenopsis orchids that bloom in later winter or early spring require a period of three to five weeks of exposure to 25 to $15{ }^{\circ} \mathrm{C}$ (77 to $59^{\circ} \mathrm{F}$ ) to trigger the emergence of the flowering stem (spiking). There is an absolute requirement for the presence of light while plants are being exposed to the proper temperatures for spiking. It is not known what factors trigger spiking of the late spring or summer blooming Phalaenopsis species and hybrids. After spiking, phalaenopsis orchids must not be exposed to temperatures above $28^{\circ} \mathrm{C}$ $\left(82^{\circ} \mathrm{F}\right)$ for extended hours. O therwise, the flowering stem will keep elongating with no flower bud differentiation, or it may produce a plantlet on the tip. It has been reported that, once spiking has occurred, $\mathrm{GA}_{3}$ ensures continued reproductive growth while plants are under $30^{\circ} \mathrm{C}\left(86^{\circ} \mathrm{F}\right)$. H owever, application of $\mathrm{GA}_{3}$ to the elongating flowering stems in the summer did not result in the differentiation of flower buds. Applying cytokinin benzylaminopurine (BA) or a combination of PBA (a cytokinin) and $\mathrm{GA}_{4+7}$ to vegetative phalaenopsis orchids failed to trigger off-season spiking. Application of cytokinin to mature dendrobium pseudobulbs, but not the developing ones, was reported to trigger inflorescence production. 